\title{
CD5 positive $B$ cells in patients with rheumatoid arthritis: phorbol ester mediated enhancement of detection
}

\author{
P YOUINOU, ${ }^{1}$ L MACKENZIE, ${ }^{3}$ J JOUQUAN ${ }^{2}{ }^{2}$ LE GOFF, ${ }^{2}$ AND \\ P M LYDYARD ${ }^{3}$
}

From the Departments of ${ }^{1}$ Immunology and ${ }^{2}$ Rheumatology, University Hospital Medical School, Brest, France; and the ${ }^{3}$ Department of Immunology, Middlesex Hospital Medical School, London

SUMmARY CD5 molecules present on human $T$ cells are detectable but weakly expressed on some human B cells. We have increased the sensitivity of their detection by treating the B enriched cells with phorbol myristic acetate (PMA), a tumour promoting agent. The numbers of CD5+ B cells in the blood of patients with rheumatoid arthritis (RA) were higher than in control blood, and after PMA treatment this was statistically significant. CD5+ B cells were also increased in tonsils, lymph nodes, and spleens after PMA activation. There were no significant differences between the percentages of B cells carrying $\varkappa$ or $\lambda$ light chains in their expression of CD5 molecules in patients with RA.

Rheumatoid arthritis (RA) is clearly an immunological disease. ${ }^{1} \mathrm{~A}$ number of aberrations have been described in the cellular arm of the immune response, for example, abnormal expression of interleukin 2 (IL2) receptors by $\mathrm{T}$ cells, ${ }^{2}$ reduced production of $\mathrm{IL}_{2}{ }^{3}$ and defective regulation of Epstein-Barr virus (EBV) response in vitro. ${ }^{4}$

Humoral processes also appear to be involved, as suggested by the presence of a large range of autoantibodies with different specificities, ${ }^{5}$ the prevalence of rheumatoid factor within synovial membrane plasma cells, ${ }^{6}$ and the high proportions of circulating $\mathrm{B}$ cells carrying receptors for mouse erythrocytes in some patients with RA. ${ }^{7}$

To characterise the $B$ cell abnormality in RA further we have focused on $B$ cells which react with anti-CD5 monoclonal antibodies, OKT $1,{ }^{8}$ Leu $1,{ }^{9}$ and MID5. ${ }^{10}$ These monoclonal antibodies react with a $67 \mathrm{kD}$ molecule which was initially shown to be present exclusively on $\mathrm{T}$ cells but is also found on most chronic lymphocytic leukaemia B cells. ${ }^{11}$ CD5 + B cells are present early in ontogeny and in germinal centres of peripheral lymphoid tissues. ${ }^{12} \mathrm{~B}$ cells staining weakly for $\mathrm{CD} 5$ antigens have also

Accepted for publication 18 June 1986.

Correspondence to Professor P Youinou, Department of Immunology, University Hospital Medical School, F29279 Brest Cedex, France. been shown on a minority of circulating B cells. Since previous data have indicated that the tumour promoter phorbol myristic acetate (PMA) increases the density of CD5 molecules on T cells (paper in preparation) and $B$ cells ${ }^{13}$ we tested the effects of PMA on enhancing their detection, especially in patients with RA.

Since experiments in mice have suggested that Lyt-1 molecules (equivalent to CD5 molecules in man) may be present especially on B cells carrying light chains ${ }^{14}$ we examined $x$ and $\lambda+$ human $B$ cells carrying CD5 molecules. In addition, since EBV immortalises only a small proportion of peripheral blood (PB) B cells ${ }^{15}$ we tested whether these cells carried CD5 molecules before and after PMA treatment.

\section{Patients and methods}

CELL SOURCE

Heparinised PB was drawn from 10 patients with RA and eight healthy volunteers from the clinical and laboratory staff. The group of patients with RA (one male, nine female) consisted of four with definite RA and six with classical disease, according to the American Rheumatism Association criteria. ${ }^{16}$ The mean age was 48 years (range 26-71) and the mean duration of disease 65 months (range 14-161) 
Table 1 Characteristics of the patients

\begin{tabular}{llllll}
\hline $\begin{array}{l}\text { Patient } \\
\text { No }\end{array}$ & $\begin{array}{l}\text { Age } \\
\text { (years) }\end{array}$ & Sex & $R F^{*}$ & $\begin{array}{l}\text { Disease } \\
\text { duration } \\
\text { (months) }\end{array}$ & Treatment' \\
\hline 1 & 42 & M & - & 123 & N \\
2 & 60 & F & + & 49 & N,D \\
3 & 37 & F & - & 26 & N \\
4 & 49 & F & + & 67 & N,D \\
5 & 68 & F & + & 161 & P \\
6 & 71 & F & + & 123 & P,D \\
7 & 26 & F & - & 18 & N \\
8 & 37 & F & - & 30 & N \\
9 & 30 & F & + & 36 & N \\
10 & 27 & F & + & 14 & R
\end{tabular}

${ }^{*} \mathrm{RF}=$ rheumatoid factor by the latex and modified Rose-Waaler tests.

$\dagger \mathrm{N}=$ non-steroidal anti-inflammatory drugs; $\mathrm{D}=\mathrm{D}$-penicillamine; $\mathrm{P}=$ prednisone.

(Table 1). Six patients were seropositive and four seronegative as determined by the latex and modified Rose-Waaler agglutination tests (Institut Pasteur Production, Paris, France). ${ }^{17}$ Treatment regimens included non-steroidal anti-inflammatory drugs (NSAIDs) alone in six cases, NSAIDs plus D-penicillamine in two, prednisone alone in one, and D-penicillamine plus prednisone in one patient.

Tonsils were obtained from children with chronic inflammation of the tonsils. Lymph nodes and samples of splenic tissue were obtained through the intensive care unit from accident victims undergoing nephrectomy for transplantation.

$B$ cell lines were obtained by EBV infection of $T$ depleted PB mononuclear cells from laboratory personnel. ${ }^{4}$ Cells were cultured at $37^{\circ} \mathrm{C}$ in a humidified atmosphere containing $5 \% \mathrm{CO}_{2}$ for at least six weeks before use in these experiments.

CELL PREPARATION

$P B$ was diluted 1:1 in Hanks's balanced salt solution and the mononuclear cells separated by density gradient separation according to Boyum ${ }^{18}$ using Ficoll-Hypaque (Eurobio, Paris, France). Adherent cells were removed by 60 minutes' incubation in Petri dishes at $37^{\circ} \mathrm{C}$, and the cell suspension was enriched with B lymphocytes by removing neuraminidase treated sheep red blood cell rosettes.

Tonsils, lymph nodes, and spleens were gently dissociated in RPMI 1640 (Flow Laboratories, Rockville, MD) containing $10 \%$ heat inactivated fetal calf serum (RPMI-FCS). Cell suspensions were centrifuged over Ficoll-Hypaque for $30 \mathrm{~min}$ at $4^{\circ} \mathrm{C}$ to remove dead cells. Interface cells were washed three times in RPMI-FCS, adherent cells removed, and the suspension enriched with $B$ lymphocytes by the neuraminidase treated sheep red blood cell rosetting technique.
CELL CULTURE

An aliquot of cells was taken as the starting population. Cells were cultured at $10 \% \mathrm{ml}$ in RPMI- $\overrightarrow{\vec{F}}$ FCS supplemented with $2 \mathrm{mM}$ glutamine, penicillin $\left(10^{5} \mathrm{U} / \mathrm{l}\right)$, and streptomycin $(100 \mathrm{mg} / \mathrm{l})$.

PMA (Sigma Chemical Co, St Louis, MO) was dissolved in acetone at $1 \mathrm{mg} / \mathrm{ml}$ and added to some cultures to give a final concentration of $10 \mathrm{ng} / \mathrm{ml}$.

Cultures were maintained in a humidified $37^{\circ} \mathrm{C}$ o incubator containing $5 \% \mathrm{CO}_{2}$ for 48 hours and $\vec{\circ}$ harvested for analysis by immunofluorescence.

Both the concentration of PMA used and the time $\stackrel{\omega}{\sigma}$ of culture were chosen after preliminary experiments on the increase in density of CD5 molecules? on T cells with the EPICS flow cytometer (Coulter के Electronics, Luton, UK).

IMMUNOFLUORESCENCE STAINING
$B$ enriched cells $\left(5 \times 10^{5}\right)$ were centrifuged and stained in 96 well $U$ bottomed plates for $30 \mathrm{~min}$ on $\mathrm{d}^{\mathrm{N}}$ ice with $50 \mu \mathrm{l}$ of purified reagents. Cells were washed in phosphate buffered saline containing $5 \% \stackrel{\text { g }}{=}$ bovine serum albumin and $0 \cdot 1 \%$ sodium azide. The reagents were: affinity purified fluorescein $\stackrel{\oplus}{\oplus}$ isothiocyanate (FITC) conjugated polyclonal. $\mathrm{F}(\mathrm{ab})_{2}{ }_{2}$ rabbit antihuman $\lambda$ chains (kindly donated by Professor J L Preud'homme, Poitiers University Medical School, Poitiers, France); monoclonal anti- כ human $x$ chains ${ }^{19}$ (kindly donated by Drs M Fanger and.E Ball, Dartmouth Medical School, NIH, USA) $\stackrel{\unrhd}{\perp}$ and detected by a second layer of FITC conjugated $\stackrel{2}{\vec{A}}$ $\mathrm{F}(\mathrm{ab})_{2}{ }_{2}$ goat antimouse IgG (Cappel Laboratories, 을 Cochranville, PA, USA) absorbed with human Cohn fraction II (Sigma, St Louis, Mo, USA); Leu $1^{9}$ coupled with biotin was purchased from Becton Dickinson (Sunnyvale, CA, USA) and used $\frac{0}{2}$ with a second layer of tetramethylrhodamine 0 isothiocyanate (TRITC) conjugated avidin. ${ }^{20}$

Two combinations were used: (a) FITC-F(ab)' ${ }_{2} \delta$ anti- $\lambda$, biotin-Leu 1, and TRITC-avidin; $(b)$ mono- $₹$ clonal anti- $x$, FITC-F(ab) ${ }_{2}$ antimouse IgG, normal 의 mouse serum to block free binding sites of antimouse and prevent binding of second mouse antibody, biotin-Leu 1, and TRITC-avidin. All reagents were titrated before use and used at plateau $\cong$ concentrations. Control experiments included the $N$ use of fluorescent second antibody reagents alone $\underset{\omega}{N}$ and examination of B enriched cells with UCHT1, a O monoclonal antibody recognising CD3 molecules ${ }^{21}$ and kindly provided by Dr P C L Beverley (University College Hospital, London). Fluorescent of preparations were viewed with a Reichert-Young 0 microscope equipped with Ploemopak vertical fluorescence illumination and a combination of $\mathbb{\mathbb { D }}$ filters and dichroic mirrors for the selective $\mathbb{D}$ visualisation of FITC and TRITC. 


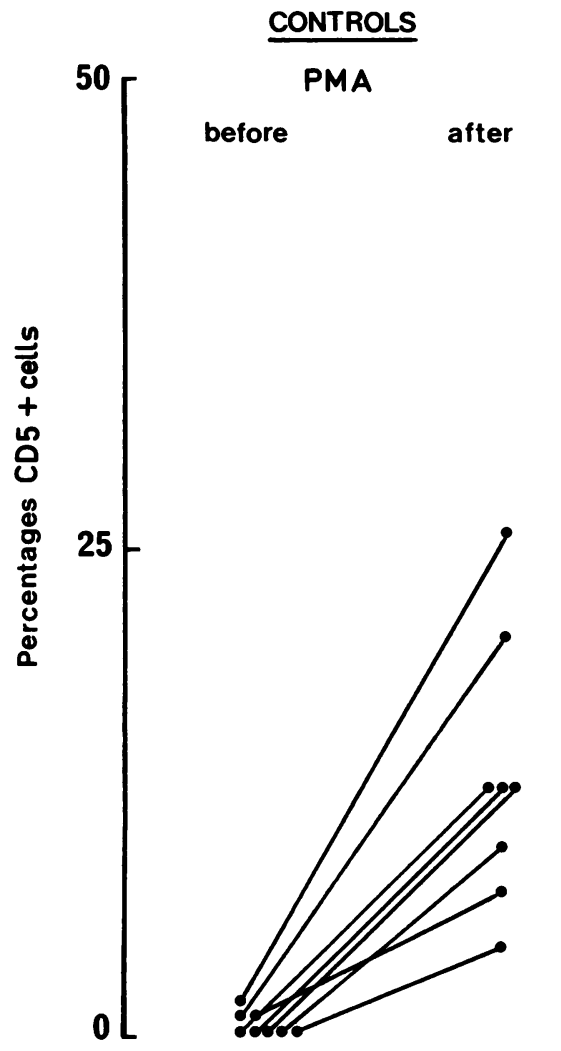

\section{RA PATIENTS}

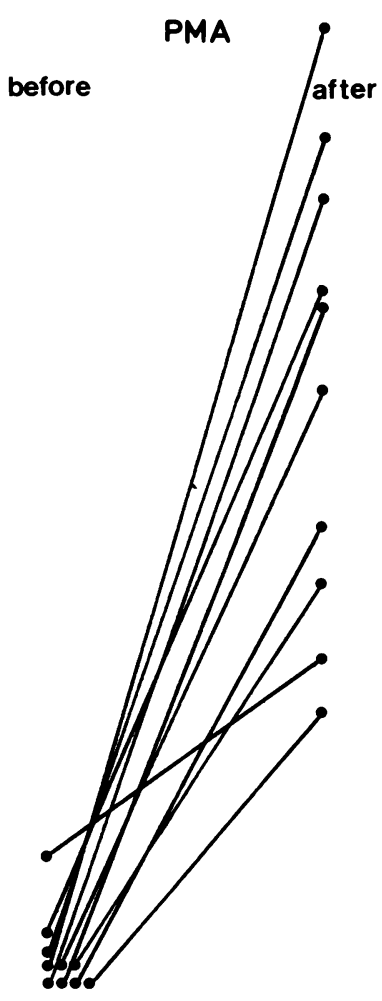

Fig. 1 Percentages of $C D 5+B$ cells in blood from controls and patients with rheumatoid arthritis, before and after incubation with PMA.

EBV lines were examined with an EPICS C flow cytometer (Coulter Electronics, Luton, UK). Mid 5 was used to identify CD5 molecules, ${ }^{10}$ and antiTac, a monoclonal antibody directed to IL2 receptors $^{22}$ (kindly provided by $\mathrm{Dr} \mathrm{T}$ A Waldmann, NIH, USA), was used as a positive control for effects of PMA on EBV B cell lines. Both monoclonal antibodies were revealed by a second layer of FITC labelled $\mathrm{F}(\mathrm{ab})^{\prime}{ }_{2}$ antimouse immunoglobulin antibody (Serotec, Oxon, UK).

STATISTICS

All data are expressed as arithmetic means \pm SEM.

Table 2 Percentages of $C D 5+B$ cells in control peripheral blood, tonsils, lymph nodes, and spleens*

\begin{tabular}{llc}
\hline Specimen & Before PMA & After PMA \\
\hline Peripheral blood $(\mathrm{n}=8)$ & $0 \cdot 5 \pm 0 \cdot 3$ & $13 \cdot 6 \pm 2 \cdot 4$ \\
Tonsil $(\mathrm{n}=6)$ & $2 \cdot 0 \pm 0 \cdot 6$ & $11 \cdot 2 \pm 4 \cdot 6$ \\
Lymph node $(\mathrm{n}=3)$ & $2 \cdot 7 \pm 0 \cdot 9$ & $7 \cdot 3 \pm 0 \cdot 3$ \\
Spleen $(\mathrm{n}=3)$ & $2 \cdot 2 \pm 0 \cdot 6$ & $26 \cdot 3 \pm 12 \cdot 8$ \\
\hline
\end{tabular}

${ }^{*}$ Values shown are mean \pm SEM.

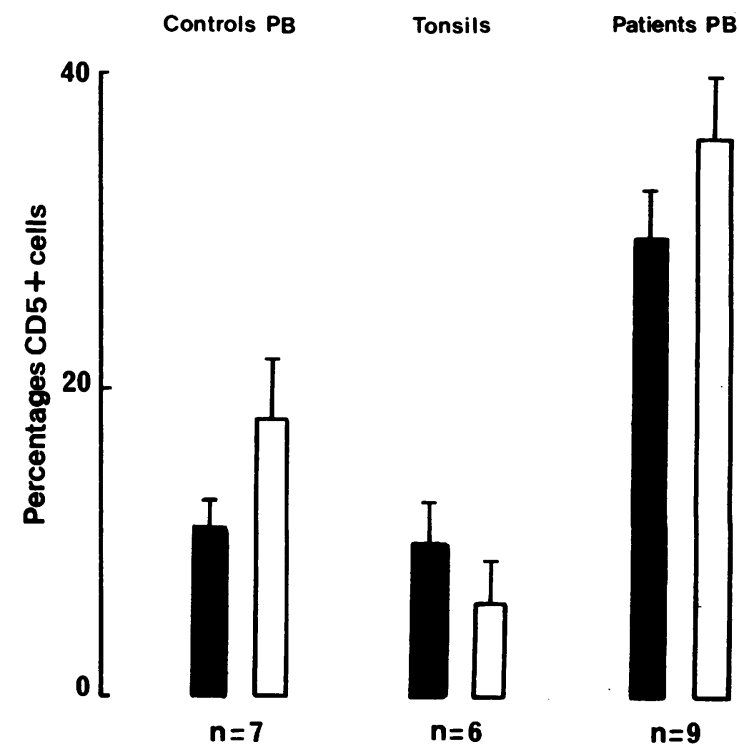

Fig. $2 B$ cells carrying $x$ or $\lambda$ light chains express $C D 5$ molecules after PMA treatment: $\square_{x}$ chains; $\square \lambda$ chains. 


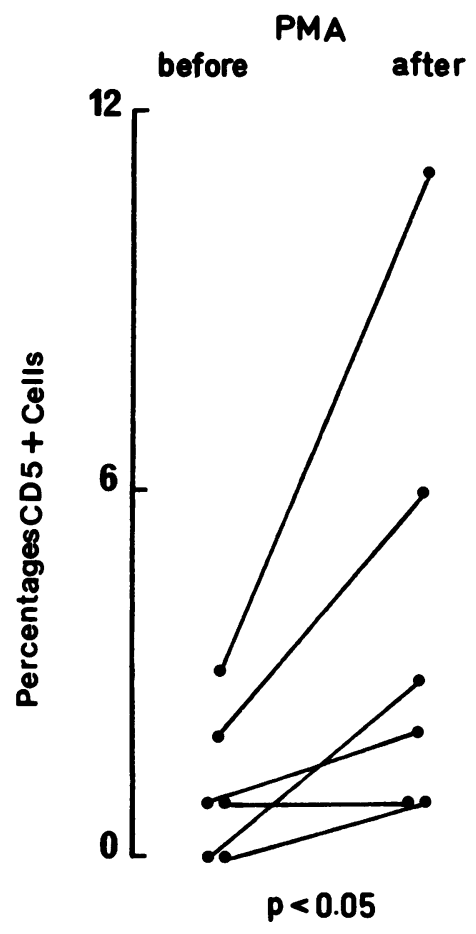

Comparisons were made by the Mann-Whitney U test for unpaired data and Wilcoxon's signed rank test for paired data.

\section{Results}

Few CD5 + cells were detectable in the PB of normal controls $(0.5 \pm 0.3 \%)$. More were found in the blood of patients with RA $(1 \cdot 8 \pm 0 \cdot 8)$, but this was not a significant enhancement. Culture with PMA, however, increased the percentages of CD5+ cells (Fig. 1) detectable in blood from both control $(13.6 \pm 2.4)$ and patients with RA (28.5 \pm 3.8$)$, and the difference between the two groups was statistically significant $(p<0 \cdot 01)$. Percentages of control CD5 + B cells were higher in tonsils, lymph nodes, and spleens than in PB (Table 2). Incubation with PMA also increased the percentages of CD5+ cells detectable.

B cells carrying either $x$ or $\lambda$ light chains can express CD5 molecules. No significant differences were seen between the percentages of $x$ or $\lambda$ chain positive B cells carrying CD5 molecules (Fig. 2). There was, however, a trend for more $\lambda$ than $x$ bearing cells to express CD5 in patients with RA. Few EBV transformed normal $B$ cells expressed
PMA before after

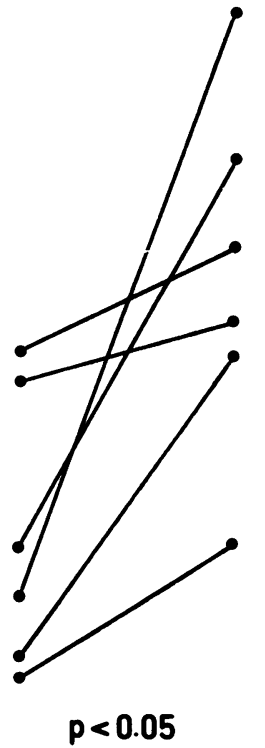

Fig. 3 Few EBV transformed $B$ cells express $C D 5$ molecules either without or with PMA treatment. Under the same conditions PMA induced receptors for IL2 on a high proportion of $B$ cells.

CD5 molecules (Fig. 3) either without $(1 \cdot 2 \pm 0 \cdot 5)$ or with PMA $(4 \cdot 0 \pm 1 \cdot 6)$ using flow cytometry. There was a small increase in CD5+ cells after PMA treatment which just reached significance $(p<0 \cdot 05)$ and also a parallel increase in IL2 receptor bearing B cells $(p<0.05)$. A significant difference $(p<0.01)$ in PMA induced CD5 + B cells also existed between normal PB and EBV transformed $B$ cells.

\section{Discussion}

CD5 molecules are weakly expressed on tonsil, lymph node, spleen, and blood B cells. There were slightly higher (but not significant) percentages of CD5 + B cells detectable in rheumatoid PB compared with control blood. After incubation with PMA the percentage of CD5 + B cells increased in all the populations of cells examined, and this treatment enhanced the differences between control and RA blood. These data support and extend the results of other investigators, who obtained high values for CD5 + cells in RA. ${ }^{23}$

Since PMA treatment results in the activation of lymphocytes it was possible that the small numbers of CD5 + cells observed in controls and especially patients with RA could represent activated cells. ${ }^{7}$ 
Activation of B lymphocytes by pokeweed mitogen $^{13}$ (and unpublished observations) or EBV, however, failed to increased expression of CD5 molecules.

The observation that CD5 molecules were only expressed on some control blood, tonsil, lymph node, and spleen cells, even after PMA treatment, indicates that this particular phenotype represents either: $(a)$ a stage of normal B cell differentiation. In this regard, CD5 + B cells have been described in developing lymphoid tissue and could represent an immature $\mathrm{B}$ cell population. ${ }^{12}(b)$ a functionally distinct $B$ cell subpopulation. It is difficult to distinguish between these two possibilities. Similar problems occur with the minor population of B cells expressing receptors for mouse erythrocytes. ${ }^{7}$

It is interesting that expression of Lyt-1 on mouse B cells might be restricted to the $\lambda+$ cells. $^{14}$ Preliminary experiments described here suggest that in man the presence of CD5 is not restricted to $B$ cell expressing $\lambda$ chains.

Since EBV activated many B cells, but immortalises only a small proportion of them, we examined whether these cells were CD5+. Few immortalised cells expressed CD5, but this was enhanced significantly, but weakly, by PMA treatment. Thus the immortalised B cells contain at least some CD5+ cells. Cloning of these B cell lines might help to define CD5+ and CD5- cells.

Experiments in mice have indicated that Lyt-1+ B cells make IgM autoantibodies in the autoimmune strain NZB. ${ }^{24}{ }^{25}$ It is interesting that, like CD5+ cells, the subsets of $B$ cells carrying receptors for mouse erythrocytes are also increased in the blood of some patients with RA. ${ }^{72627}$ Some of the B cells carrying these receptors can be induced to secrete IgM rheumatoid factor ${ }^{28}$ and express CD5 molecules. ${ }^{12}$ Thus one might speculate that defective regulation of these $B$ cell subsets could give rise to the high levels of rheumatoid factors in patients with RA.

We thank Dr B Bourbigot for providing some tissues, Professor J L Preud'homme and Drs M Fanger, E Ball, P C L Beverley, and T A Waldmann for donating some reagents, and Ms S Forest for expert secretarial assistance. This work was supported by a grant from the Ministère de l'Industrie et de la Recherche, France and the Medical Research Council, UK.

\section{References}

1 Lydyard P M, Irving W L. Immunological aspects of rheumatoid arthritis. In: Saunders K B, ed. Advanced medicine. Vol. 19. London: Pitman Medical. 1983: 156-65.

2 Youinou P, Courtois B, Casburn-Budd R, et al. Interleukin-2receptor-bearing helper $\mathrm{T}$ cells in the joint of rheumatoid arthritis patients. Int $J$ Immunotherapy 1985; i: 261-6.

3 Miyasaka N, Nakamura T, Russel I J, Talal N. Interleukin-2 deficiencies in rheumatoid arthritis and systemic lupus erythematosus. Clin Immunol Immunopathol 1984; 31: 109-17.

4 Irving W L, Walker P R, Lydyard P M. Abnormal responses of rheumatoid arthritis lymphocytes to Epstein-Barr virus infection in vitro: evidence for multiple defects. Ann Rheum Dis 1985; 44: 462-8.

5 Holborow E J. Autoantibodies in rheumatoid arthritis: some new facts. Clin Immunol Allergy 1981; 1: 127-38.

6 Youinou P Y, Morrow W J W, Lettin A W F, Lydyard P M, Roitt I M. Specificity of plasma cells in the rheumatoid synovium. I. Immunoglobulin class of antiglobulin-producing cells. Scand J Immunol 1984; 20: 307-14.

7 Youinou P Y, Irving W L, Shipley M, Hayes J, Lydyard P M. Evidence for $B$ cell activation in patients with active rheumatoid arthritis. Clin Exp Immunol 1984; 55: 91-8.

8 Reinherz E L, Kung P C, Golstein G, Schlossman S F. A monoclonal antibody with selective reactivity with functionally mature human thymocytes and all peripheral human T cells. $J$ Immunol 1979; 123: 1312-7.

9 Engleman E G, Benike C J, Glickman E, Evans R L. Antibodies to membrane structures that distinguish suppressor/ cytotoxic and helper $\mathrm{T}$ lymphocyte subpopulations and block the mixed lymphocyte reaction in man. J Exp Med 1981; 154: 193-8.

10 Guarnotta G, Campbell M A, Harte A, et al. Analysis of two monoclonal antibodies defining the majority and a subset of human T cells. In: Bernard A, Boumsell L, Dausett J, Milstein C, Schlossman S F, eds. Lymphocyte typing, human leucocyte differentiation antigens detected by monoclonal antibodies. Berlin: Springer, 1984: 312-5.

11 Martin P J, Hanson J A, Siadak A W, Nowinski R C. Monoclonal antibodies recognizing normal human $T$ lymphocytes and malignant human B lymphocytes: a comparative study. J Immunol 1981; 127: 1920-3.

12 Caligaris-Cappio F, Gobbi M, Bofill M, Janossy G. Infrequent normal B lymphocytes express features of B-chronic lymphocytic leukemia. J Exp Med 1982; 155: 623-8.

13 Miller $\mathrm{R} A$, Gralow $J$. The induction of Leu-1 antigen expression in human malignant and normal $\mathrm{B}$ cells by phorbol myristic acetate (PMA). J Immunol 1984; 133: 3408-14.

14 Braun J. Spontaneous in vitro occurrence and long-term culture of murine B lymphoblast cell lines. J Immunol 1983; 130: 2113-6.

15 Bird A G, Britton S, Ernbeerg I, Nilsson K. Characteristics of Epstein-Barr virus activation of human B lymphocytes. $J$ Exp Med 1981; 154: 832-9.

16 Ropes M W, Bennett G A, Cobb S, Jacox R, Jessar R A. Diagnostic criteria for rheumatoid arthritis: 1958 revision. Ann Rheum Dis 1959; 18: 49-53.

17 Podliachouk L, Eyquem A, Jacqueline F. Le diagnostic de la polyarthrite chronique évolutive par agglutination des globules rouges humains sensibilisés. Ann Institut Pasteur 1958; 94: $659-62$.

18 Boyum A. Isolation of mononuclear cells and granulocytes from human blood. Scand J Clin Lab Invest 1968; 21 (suppl): 77-9.

19 Lowe J, Hardie D, Jefferis R, et al. Properties of monoclonal antibodies to human immunoglobulin kappa and lambda chains. Immunology 1981; 42: 649-59.

20 Guesdon J L, Ternynck T, Avrameas S. The use of avidinbiotin interaction in immunoenzymatic techniques. $J$ Histochem Cytochem 1979; 27: 1131-9.

21 Beverley P C L, Callard R E. Re-definition of human T cells by monoclonal antibodies. In: Peeters $\mathrm{H}$, ed. Protides of the biological fluids, Vol. 29. Oxford: Pergamon, 1981: 653-8.

22 Uchiyama I, Broder S, Waldmann T A. A monoclonal antibody (anti-Tac) reactive with activated and functionally mature human $T$ : :ils. I. Production of anti-Tac monoclonal antibody and distr!:uuull of Tac (+) cells. J Immunol 1981; 126: 1393-7. 
22 Youinou, Mackenzie, Jouquan, Le Goff, Lydyard

23 Plater-Zyberk C, Maini R N, Lam K, Kennedy T D, Janossy G. A rheumatoid arthritis $B$ cell subset expresses a phenotype similar to that in chronic lymphocytic leukemia. Arthritis Rheum 1985; 28: 971-6.

24 Mahonar V, Brown E, Leiserson W M, Chused T M. Expression of Lyt-1 by a subset of B lymphocytes. J Immunol 1982; 129: $532-8$.

25 Hayakawa $\mathrm{K}$, Hardy $\mathrm{R} \mathrm{R}$, Honda $\mathrm{M}$, Herzenberg L A, Steinberg A D, Herzenberg L A. Lyt-1 B-cells: functionally distinct lymphocytes that secrete IgM autoantibodies. Proc Natl Acad Sci USA 1984; 81: 2494-8.
26 Stathopoulos G, Elliott E V. Formation of mouse or sheep red blood cell rosettes by lymphocytes from normal and leukaemic individuals. Lancet 1974; i: $600-1$.

27 Room G R W, Plater-Zyberk C. Clarke M F, Maini R N. B-lymphocyte subpopulation which forms rosettes with mouse erythrocytes increased in rheumatoid arthritis. Rheumatol Int 1982; 2: 175-8.

28 Fong S, Vaughan J H, Carson D A, Two different rheumatoid factor-producing cell populations distinguished by the mouse erythrocyte receptor and responsiveness to polyclonal B cell activators. J Immunol 1983; 130: 162-4. 